\title{
Clothing Practices of Tribal Women of Udaipur Sub-area
}

\author{
Dolly Mogra ${ }^{1}$ and Simple Jain ${ }^{2}$ \\ ${ }^{1}$ Mohanlal Sukhadia University, Udaipur, Rajasthan, India \\ ${ }^{2}$ Department of Home Science Extension and Community Management, ASPEE College of \\ Home Science and Nutrition, SDAU, Sardarkrushinagar, Banasakantha, Gujarat, India

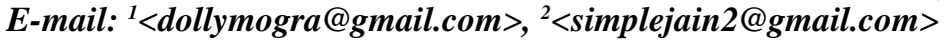

KEYWORDS Storage. Fashion. Fitting. Iron Box. Mulmul

\begin{abstract}
This study investigated the clothing storage practices of women living in tribal areas of Udaipur. Specifically the study determined: storage facilities and materials used by the women; ways they store different types of clothing articles, clothing practices. The study adopted a survey research design. The area of study was 'Jhadol' Tehsil of Udaipur district. A sample of 120 respondents was used for study. Questionnaire, interview and informal discussions were used as tool for data collection. Data were analyzed using frequency and percent. Findings include that clothing selection was highly influenced by socio-religious factors, sixty-three percent respondents bought clothes for themselves, and fifty-one percent purchased clothing from open air market. Tribal women were least aware of brand names. Majority of them were affected by fashion, fitting, colour and price. Iron boxes (85\%), ropes string (59\%) and storing in tight wrappers (64\%) was used for storing purpose. Only twelve percent used mulmul fabric to wrap heavy clothes before storage and similar percent was aware about the importance of clean and dry storage areas. It is recommended that proper guidelines should be given to tribal women through workshops, training programmes to improve clothing storage practices.
\end{abstract}

\section{INTRODUCTION}

The term tribe refers to a cultural and historical concept. It is used in terms of folk urban continuum along which different groups are classified, given a certain order of material, culture and stage of technological growth and classified as tribes. According to Oxford Dictionary "tribe is a group of people in primitive or barbarous stage of development acknowledging the authority of a chief and usually regarding themselves as having a common ancestor."

Clothing is a factor in every day human life and interactions with others. Clothing is a systematic means of transmitting information about the wearer. Proper care and storage of clothes help to keep them in good condition so that appearance of the wearer is enhanced. Proper storage of clothes involves decision making. Decision making is the action taken in selecting from alternative courses of action (Anyakoha and Eluwa 2007). Clothing storage decisions include, among others, storage facilities, ways of storing specific items, factors that influence the procedures to adopt. Storage of clothes provides protection from dust, dirt, insects, fungus and dye transfer (Marshal et al. 2000). Adequate storage space for clothing and the way it is used, however, are management considerations (Wood-
Ward 2006). Everyone needs suitable places to store clothes - a closet or place to hang some garments and shelves or other articles (Marshal et al. 2000). Hanging clothes in wardrobes prevents them from getting creased or rumpled so that they can retain their original shape (Anyakoha and Eluwa 2007). Taking proper storage of clothes in addition to making them look better, also makes them last longer. Women have multiple responsibilities in the homes and outside the homes, including the management of family clothing. Storage of clothes is an important aspect of this management. Some women who live in rural areas are therefore often seen with poorly maintained clothes. Such clothes, if not cleaned and re-furbished, will smell, itch, look untidy, and lose functionality (WoodWard 2006). Improper clothing storage practices of the women living in rural areas can lead to skin diseases, bad odour, feeling of unwholesome attitude and poor adjustment to social groups (Marshal et al. 2000). Ohwvoriole and Ugeru (2002) stated that the knowledge of proper storage is very important. Acquisition of specialized skills is paramount to all practical oriented skills such as clothing care (Okoro 1999). It is therefore necessary to seek ways of helping the women in the rural areas to improve on their storage practices. A meaningful step in this direction is to deter- 
mine their present storage practices as a basis for determining ways of helping them. However, little research has been conducted regarding the clothing and storage practices of tribal women.

\section{Objectives}

The major purpose of this study was to investigate the clothing and storage practices among tribal women living in tribal areas of $\mathrm{Jh}$ adol tehsil. The other objectives include:

- To identify clothing and their demographic profile

- To collect information about jewellery of tribal women

- To find out the storage facilities and materials adopted by women in storing their clothes

- To find out ways in which women store different clothing articles

\section{METHODOLOGY}

\section{Sample of the Study}

A multi-stage sampling technique was used in the selection of respondents for the study. Selection of respondents for the survey was done on the basis of stratified random sampling method, covering all the hamlets.

\section{Study Area}

The study has been conducted in the four purposefully selected villages from the Jhadol tehsil of Udaipur district of Indian state of Rajasthan. Four villages were purposively selected from Jhadol tehsil (Kolyari, Bagpura-madri, Palyakhera, Palasiya). From each village, 30 women were randomly selected belonging to Bhil, Daamor, Katara, Garasia caste. In general the total sample of the study was one hundred and twenty (120) tribal women living in the tribal areas. The women were met at their various homes and some on their farms.

\section{Instrument Development}

Two-step research design was developed. Step one consisted of a qualitative preliminary study to explore clothing and storage practices. The following research questions guided the study: How do individuals select clothing and why? In what ways can clothing be used to express the self and social identity? What does clothing storage represent to tribal women? What meanings do tribal women assign to clothing storage practices and why?

These findings were then used to guide the development of the conceptual framework and research instrument employed for the second step. The instrument was face validated by three Home Science (Clothing and Textile specialist) lecturers, from the College of Home Science, Maharana Pratap University of Agriculture and Technology, Udaipur. To ensure the reliability of the instrument, 30 copies were administered to 30 women living in tribal areas in villages of Jadhol.

\section{Data Collection and Analysis Techniques}

Data were collected using interview schedule and informal discussions. One hundred and twenty copies of the questionnaire were distributed to respondents. The questionnaire served as interview schedule for the illiterate respondents and their responses were recorded. There were several types of locations used for data collection to allow for greater sample generalization. Local Mewari language was used for data collection.

\section{RESULTS AND DISCUSSION}

\section{Demographic Profile of the Respondents}

The respondents were within age range of 30 to 60 years old. The respondents consisted of females and all were married (100\%). There were no divorced, widowed, or widower respondents in the sample. The dominant religion practiced by the participants was Hinduism. It is apparent from Table 1 that 25.83 percent were illiterate in comparison to 3.33 percent of graduates. Young generation has started to take interest in education as accessibility of education is much easier nowadays. Regarding income of the family in the financial year of 2011-2012; 11.67 percent respondents earn more than Rs.10,000 per month on an average due to good rainy season. Only 11.67 percent reported about less than Rs. 5000 per month. It was discussed that they didn't have any fixed income, it fluctuated according to season and work. Table 1 clearly depicts that majority of females was associated 
Table 1: Demographic characteristics of the respondents $(n=120)$

\begin{tabular}{llrr}
\hline & Characteristics & Frequency & Percent \\
\hline Age & Older group (30 to 45 years) & 60 & 50.00 \\
Education & Younger group (46 to 60 years) & 60 & 50.00 \\
& Illiterate & 31 & 25.83 \\
& Finished primary school & 39 & 32.50 \\
& Finished middle school & 31 & 25.83 \\
& Finished high school & 14 & 11.67 \\
Household Income & Completed college & 4 & 3.33 \\
& Other & 1 & 0.83 \\
& Less than Rs. 5000 per month & 14 & 11.67 \\
& Up to Rs. 6000 per month & 67 & 55.83 \\
Employment & Up to Rs. 10000 per month & 25 & 11.63 \\
& More than Rs. 10000 per month & 14 & 1.67 \\
& Only housewife & 2 & 6.67 \\
& Only farming & 8 & 9.17 \\
& Only Contractual worker & 11 & 6.67 \\
& Only service -government & 8 & 11.67 \\
& Only service-private & 14 & 7.50 \\
& Only maid & 9 & 56.67 \\
\hline
\end{tabular}

with some type of work either farming (6.67\%) or Government job (6.67\%). It was concluded that tribal women engaged themselves in work according to availability so they were associated with farming and other type of activities to earn money. 56.67 percent of females were doing multiple jobs. Besides farming, they were doing contractual work in Government and private institutions.

\section{Clothes of Tribal Women}

Traditional clothes of tribals have uniqueness in style, colour and decoration. Jamsai, nandana, katki, rensai, lugda, odhni,jwar-bhat, odhni leher bhat, odhni tara bhat and chunad are major clothes used by tribal women. Blouse (upper garment), lehenga and odhni are common dresses of tribal women. Respondents discussed about following traditional clothes:

\section{Choli (Blouse)}

This is an upper garment also known as angruthi popular among Bhil tribe women.

\section{Lehenga (Lower Skirt)}

It is known as gaghra or Kachavo worn by Bhil tribe to cover legs and tied on waist.

\section{Jamsai Saree}

This saree is worn at the time of marriage; it has red background with flowers and leaves in sequence (bel). On red background it has white and black bhat (motif). Lehenga (lower skirt) is also prepared by the same design and colour scheme.

\section{Nandana/Nanada}

It is the oldest cloth used by tribal women; it is of blue colour having small geometrical squares. Butterfly motifs, small plant motif with six leaves and six fruits are very popular patterns. It is printed with resist technique named as Dabu printing.

\section{Katki}

It is used by unmarried girls; the background is red with buti (motif) of white and black. For white background dabu resist technique was used.

\section{Pawali/ Pavali Bhat ki Odhni}

It has circle and one small bindki (small filled circle) printed in middle of circle, six small circles are placed outside the circle. All over this circle motif is scattered with red and black border.

\section{Rainsai}

It is lehenga (lower skirt)design on which black background is printed with red and brown buties (motif). The motif is inspired by "Thor" plant that is thorny. The border is prepared with bel (sequential motif). 


\section{Lugada}

It is known as Angocha Saree worn by married women. Kairi (mango) buta is popularly used with white background and red buties. On borders small mango motif is printed. Chitdar (dotted) lugdi has dimension of 2.10 to 2.25 metre in length and 1.25 to 1.35 meter in width.

\section{Jwar Bhat ki Odhni}

It is very much liked by tribal women. It has red and black motifs on white background. It is similar to grain of Jwar that is main food grain of Rajasthan. The odhni is upper garment to cover head and tucked in lehenga. Small dots are visible from distance and pallu (head part of odhni) and border is printed with flowers and bel-buti.

\section{Leher Bhat ki Odhni}

This resembles like diagonal printed lines but actually diagonal line effect was given through jwar bhat (motif), the border and pallu is similar to Jwar bhat ki odhni.

\section{Kairi Bhat ki Odhni}

This odhni is prepared with red background having mango motif on borders and pallu. Overall white and yellow dots were printed.

\section{Tara Bhat ki Odhni}

This is very much popular and liked by tribal women. It has brick colour background, it is prepared with white colour hexagonal buti that looks like star. In local language star means "Tara".

\section{Chunad}

At some time in ayad area of Udaipur bhilo ki chunari was commercially produced. The background is of red-brick colour and small dots are of white colour that is prepared with tie and dye technique. Blocks with bird motif was used and red, yellow, green, pink was popular. But nowadays screen printed fabric is popular due to cost effectiveness.

\section{Fabric}

It was observed that previously pure cotton fabric weaved at handloom was used but now polyester and other blended fabric is common. Screen printing has replaced hand block printing and dying techniques.

\section{Surface Enrichment Techniques}

Impact of fashion is also visible in surface enrichment techniques of dresses worn by tribal women. Bead, sequence, gotta patti work, golden and silver thread work, laces are used lavishly on traditional clothing. Workmanship is not yet good but still popular among tribal women.

\section{Jewellery}

Respondents were fond of jewellery and they used to wear it; they reported that most of the jewellery is made up of silver but now artificial jewellery was also becoming popular. According to Sharma et al.(2008) tribe jewellery is classified in reference to body parts is given in Table 2 .

Table 2: Classification of tribal jewellery

\begin{tabular}{|c|c|c|}
\hline $\begin{array}{l}\text { S. } \\
\text { No. }\end{array}$ & $\begin{array}{l}\text { Body } \\
\text { part }\end{array}$ & Jewellery name \\
\hline 1. & Head & $\begin{array}{l}\text { Shishful, tika, rakdi, surbhang, borla, } \\
\text { fini, memdi etc. }\end{array}$ \\
\hline 2. & Ear & $\begin{array}{l}\text { Karnful, murki, bali, long, zhale, tops, } \\
\text { bareth, eron, bhuchariya, surliya, } \\
\text { morcover, patisuliya etc. }\end{array}$ \\
\hline 3. & Hands & $\begin{array}{l}\text { Chudi, tadda, kade, noungari, dastband, } \\
\text { gokru, gajra, hathful, chatala, anguthi, } \\
\text { mundadi etc. }\end{array}$ \\
\hline 4. & Neck & $\begin{array}{l}\text { Kanthi, khungali, thimania, hansali, } \\
\text { thussi, chandanhaar, aad, matarmala, } \\
\text { jantar, haar, janjir, guliband, jalar, } \\
\text { mandali, halaro, mohran etc. }\end{array}$ \\
\hline 5. & Leg & $\begin{array}{l}\text { Payejeb, kada, taneke, chutki, challa, } \\
\text { bichuye, ramjod, payal etc. }\end{array}$ \\
\hline 6. & Teeth & Chup, rakan etc. \\
\hline 7. & Waist & $\begin{array}{l}\text { Karghani, satka, tagdi, kandor, janjir } \\
\text { etc. }\end{array}$ \\
\hline 8. & Nose & $\begin{array}{l}\text { Nath, long, latkan, bari, chuni, choup } \\
\text { etc. }\end{array}$ \\
\hline
\end{tabular}

\section{Degree of Social-religious Influence on Dress Selection of Respondents}

Respondents were asked to rate on a scale of 1 to 5 about social-religious factor that influenced their dress practices with 1 being no influence and 5 being very strongly influenced. Fifty six (46.67\%) respondents stated their religion influences their dress practices strongly or (20.83\%) very strongly. As shown in Table 3, 
thirteen respondents (10.83\%) stated that religion influenced somewhat what they wore. Nineteen $(15.83 \%)$ of the respondents were influenced a little or (5.83\%) not at all in their dress by their affiliated social-religion.

Table 3: Degree of social-religious influence on dress selection of respondents $(n=120)$

\begin{tabular}{lcc}
\hline Category & Frequency & Percent \\
\hline Does not influence & 7 & 5.83 \\
Influences a little & 19 & 15.83 \\
Influences somewhat & 13 & 10.83 \\
Influences strongly & 56 & 46.67 \\
Influences very strongly & 25 & 20.83 \\
\hline
\end{tabular}

Note: Does not influence=1; Influence a little=2; influences somewhat $=3$; influences strongly $=4$; and influences very strongly $=5$

\section{Clothing Acquisition Practice}

The findings in Table 4 show that most (52.50\%) of the respondents' clothing were mainly bought by themselves and particularly with their husbands and relatives. 11.67 percent of them mainly acquired the clothing from siblings, five percent received from parents as gift on various occasions and fifteen percent had acquired the clothing by relatives. Similar percent (15.83\%) had acquired clothing from other sources like NGOs, lottery, free gifts from shop keepers as illustrated by tribal women.

Table 4: Respondents' clothing acquisition practice $(\mathbf{n}=120)$

\begin{tabular}{lcr}
\hline Category & Frequency & Percent \\
\hline Buy for myself & 63 & 52.50 \\
From siblings & 14 & 11.67 \\
Gifted by parents & 6 & 5.00 \\
Relatives & 18 & 15.00 \\
Other sources & 19 & 15.83 \\
\hline
\end{tabular}

\section{Buying Preference}

This variable was considered because buying place may have an impact on clothing satisfaction of an individual. A majority (42.50\%) of the respondents' clothing were bought from outlets selling new clothing in open air market especially from village fairs where 34.17 percent of them were from the shops (Table 5).

Second hand clothes were also purchased by some tribal female ( $7.50 \%$ and $4.17 \%)$; respondents $(11.67 \%)$ reported that other sources like vendors, sourcing from other urban places were also popularized.

Table 5: Buying preference of the respondents $(n=120)$

\begin{tabular}{lcc}
\hline Category & Frequency & Percent \\
\hline $\begin{array}{l}\text { Shops selling new clothes } \\
\begin{array}{l}\text { Shops selling second-hand } \\
\text { clothes }\end{array}\end{array}$ & 41 & 34.17 \\
$\begin{array}{l}\text { Open air markets selling } \\
\text { new clothes }\end{array}$ & 51 & 7.50 \\
$\begin{array}{l}\text { Open air markets second- } \\
\text { hand clothes }\end{array}$ & 5 & 42.50 \\
\begin{tabular}{l} 
Other sources \\
\hline
\end{tabular} & 14 & 4.17 \\
\hline
\end{tabular}

This might have had an influence on clothing satisfaction since most of the respondents had their clothes bought from a common place as their friends' hence common clothing features. These findings concurred with Migunde's (1993) and Marinda's (2001) on clothing of the adolescents where open-air market selling second-hand clothes was a popular source of clothing.

\section{Factors Considered in Clothing Selection}

Factors that one considers in clothing selection reflects an individuals' clothing preference which in turn affects clothing satisfaction/ dissatisfaction.

Table 6: Factors considered in clothing selection $(\mathbf{n}=120)$

\begin{tabular}{lccc}
\hline Category & $\begin{array}{c}\text { Always } \\
(\%)\end{array}$ & $\begin{array}{c}\text { Sometimes } \\
(\%)\end{array}$ & $\begin{array}{r}\text { Never } \\
(\%)\end{array}$ \\
\hline $\begin{array}{l}\text { Family preference } \\
\text { Peer group }\end{array}$ & 44 & 55 & 1 \\
$\quad 37$ & 51 & 12 \\
$\quad \begin{array}{l}\text { preference } \\
\text { Religious beliefs/ }\end{array}$ & 43 & 43 & 14 \\
$\quad$ Norms & & & \\
Media/Movies & 23 & 53 & 24 \\
Comfort & 43 & 53 & 4 \\
Colour & 67 & 33 & 0 \\
Fashion & 38 & 49 & 13 \\
Brand names & 0 & 3 & 97 \\
Fitting & 76 & 24 & 0 \\
Price & 95 & 4 & 1 \\
Style/Design & 55 & 43 & 2 \\
\hline
\end{tabular}

\section{Factors Related to Socio-cultural Factors}

These are factors related to the society as a whole and one's cultural background. Family 
preference, religious beliefs and media were included as a whole for socio-cultural factors.

\section{Family Preference}

The findings show that a majority (55\%) of the respondents were sometimes influenced by their family's taste in their clothing selection while forty-four percent respondents were always influenced. This shows that family members' influence was one of the major factors influencing clothing selection among the respondents and this could be due to the respondents' dependence on their husband and in-laws for their clothing provision.

\section{Peer Group Preference}

As shown inTable 6, peer group sometimes influenced fifty-one percent of the respondents who answered the question while thirty-seven percentrespondents were always influenced. Twelve percent respondents were never influenced by the peer group. The results indicate that peer group acceptance was also a major factor considered in the respondents' clothing selection. This result agrees with Migunde's (1993) and Wilson and Gillivray (1998) on factors considered in clothing selection, who found that peer group was a major factor considered in clothing selection.

\section{Religious Beliefs/Norms}

Religious beliefs/norms were highly influential factor for forty-three percent of those who responded to the question were always influenced by them while forty-three percentrespondents were sometimes influenced and fourteen percentrespondents were never influenced by it. This could be due to the fact that the respondents were greatly influenced by urban life where they were mixed up with people from varying religious/cultural backgrounds hence weakening their ties to their respective religions/cultures. The finding concurs with Migunde's (1993) and Otieno's (1990) on factors considered by adults in clothing selection within Kenyatta university, who found that religious beliefs/norms were less influential factors to their clothing selection.

\section{Media/Movies}

Media/movies were the highly influential factors of the four socio-cultural factors since a majority (53\%) of those who responded to the question was sometimes influenced and twenty-three percentrespondents were always influenced. This could be due to the fact that the respondents spent most of their time in economic activities such that they had less time to concentrate on fashion related to media/movies. Media/movies may also have been expensive for most of tribal women to afford. This also concurred with Wilson and Gillivray (1998) who found that media/movies were major factors influencing clothing selection.

\section{Factors Related to Clothing Characteristics}

These are factors such as texture/comfort, colour, latest fashion, brand name, size and fashionability of the clothing that relate to the nature of the clothing. The results are as shown in (Table 6).

\section{Texture/Comfort}

Texture/comfort was highly influential factor to the respondents' clothing selection, as forty-three percent were always influenced, fifty-three percent of those who responded to the question were sometimes influenced while four percent were never influenced.

\section{Color}

Color was a very influential factor because sixty-sevenpercent of the respondents who answered the question were always influenced by it and thirty-three percent were sometimes influenced. Most respondents were therefore very sensitive to the visual appearance of the clothing worn.

\section{Latest Fashion}

A larger proportion (49\%) of the respondents who answered the question was sometimes influenced by the latest fashion, thirty-eight percent were always influenced and thirteen percent were never influenced by the factor. The latest fashion was a popular factor considered because the respondents were conscious of the appearance of those around them hence their latest clothing styles.

\section{Brand Name}

Brand name of the clothing had a very low influence on the respondents' clothing selec- 
tion; ninety-seven percent of the respondents who responded to the question were never influenced by it, three percent were sometimes influenced. This agrees with Migunde's (1993) and Marinda's (2001) findings on the clothing and this could be due to lack of the respondents' awareness of the clothing brand names in the market.

\section{Fitting of the Clothing}

As shown in Table 6, a majority (76\%) of the respondents who answered the question was always influenced by fitting of the clothing, twentyfourpercentrespondents were sometimes influenced.

\section{Style/Design of the Clothing}

The findings showed that a majority (55\%) of those who responded to the question was always influenced by style/design of the clothing, forty-threepercentrespondents were sometimes influenced and twopercentrespondents were never influenced. The implication of this is that the style or design feature of the clothing being selected was moderately considered by the respondents. Among the above factors related to clothing characteristics, brand name of the clothing was the least influential factor in the clothing selection.

\section{Storage Facilities}

Table 7 shows that storage facilities are used by the tribal women to keep their clothes in good condition. Most of them were aware about storing facilities and they were intellectual in using available resources for maximum use. As looking at their poor economic background proper furniture and hangers were not found in their homes. But youngsters were found aware about latest wardrobe styles as well as techniques of storing different types of fabrics. Neem leaves were always used by majority of respondents (41\%) whereas twenty-eight percent respondents were sometimes using mildew and moth proof balls. Eighty-five percent respondents always used iron boxes; on the other hand thirty-three percent respondents never used wardrobes and closets. Ropes string was easily available and always used by fifty-nine percent of respondents. Home furnishing articles store on table Hangers and clips were uncommon stor- ing practices followed by respondents. This is in line with Pitts and Wessel (2006) who stated that special fabric needs special care and that moth often damages articles that are not stored properly. The findings were in agreement with David (2009) who stated the need for an existing infrastructure that will enable educational programmes in rural areas.

Table 7: Storage facilities $(n=120)$

\begin{tabular}{|c|c|c|c|c|}
\hline $\begin{array}{l}\text { S. } \\
\text { No. }\end{array}$ & $\begin{array}{l}\text { Storage } \\
\text { facilities }\end{array}$ & $\begin{array}{c}\text { Always } \\
\text { (\%) }\end{array}$ & $\begin{array}{c}\text { Sometimes } \\
(\%)\end{array}$ & $\begin{array}{l}\text { Never } \\
(\%)\end{array}$ \\
\hline 1. & Iron boxes & 85 & 12 & 3 \\
\hline 2. & $\begin{array}{l}\text { Wardrobes and } \\
\text { closets }\end{array}$ & 25 & 42 & 33 \\
\hline 3. & Shelves & 59 & 37 & 4 \\
\hline 4. & Hangers & 17 & 32 & 51 \\
\hline 5. & Clips & 5 & 9 & 86 \\
\hline 6. & Ropes string & 59 & 31 & 10 \\
\hline 7. & Storage spaces & 49 & 46 & 5 \\
\hline 8. & Cartons & 43 & 38 & 19 \\
\hline 9. & $\begin{array}{l}\text { Storing in tight } \\
\text { wrappers }\end{array}$ & 64 & 21 & 15 \\
\hline 10. & Pots & 47 & 46 & 7 \\
\hline 11. & Insect repellant & 23 & 49 & 28 \\
\hline 12. & Neem leaves & 41 & 39 & 20 \\
\hline 13. & $\begin{array}{l}\text { Moth balls and } \\
\text { cedar }\end{array}$ & 3 & 28 & 69 \\
\hline
\end{tabular}

\section{Storage Practices of Different Types of Clothing Articles}

Table 8 indicated lack of skills in the storage practices as tribal women had less exposure, knowledge and resources to keep dresses in right manner. All of them were not very particular about clothing storage practices. Eighty-three percent respondents sometimes clean outfits thoroughly before packing. Only twenty-eight percent respondents always used cardboard boxes, fifty-six percentrespondents always used newspaper for storage and fifty-four percent respondents never used mulmul fabric to wrap heavy dresses.

\section{CONCLUSION}

This study has investigated the present status of storage practices in tribal areas of Jhadol tehsil of Udaipur district. It determined the practices adopted by women in storing their clothes, the storage facilities adopted by women, and the storage of different types clothing articles and clothing practices. 
Table 8: The storage practices of different types of clothing articles $(n=120)$

\begin{tabular}{|c|c|c|c|}
\hline $\begin{array}{l}\text { Storage } \\
\text { technique }\end{array}$ & $\begin{array}{c}\text { Always } \\
(\%)\end{array}$ & $\begin{array}{c}\text { Sometimes } \\
(\%)\end{array}$ & $\begin{array}{r}\text { Never } \\
(\%)\end{array}$ \\
\hline $\begin{array}{l}\text { Clean all outfits } \\
\text { thoroughly before } \\
\text { packing }\end{array}$ & 14 & 83 & 3 \\
\hline $\begin{array}{l}\text { Cardboard boxes } \\
\text { can be used for } \\
\text { temporal storage }\end{array}$ & 28 & 42 & 30 \\
\hline $\begin{array}{l}\text { Use new clean boxes } \\
\text { to avoid staining } \\
\text { and insects }\end{array}$ & 52 & 38 & 10 \\
\hline $\begin{array}{l}\text { Be aware that cup- } \\
\text { board boxes do } \\
\text { not attract bugs }\end{array}$ & 27 & 24 & 49 \\
\hline $\begin{array}{l}\text { Line containers } \\
\text { with news paper }\end{array}$ & 56 & 34 & 10 \\
\hline $\begin{array}{l}\text { Fold knitted, items } \\
\text { and place into } \\
\text { storage container }\end{array}$ & 24 & 39 & 37 \\
\hline $\begin{array}{l}\text { Wrap the heavy } \\
\text { clothing in mulmul } \\
\text { fabric }\end{array}$ & 12 & 34 & 54 \\
\hline $\begin{array}{l}\text { Storage area must be } \\
\text { clean and dry to } \\
\text { protect clothes }\end{array}$ & 12 & 31 & 57 \\
\hline
\end{tabular}

Based on the findings, the storage activities are not practiced effectively by women living in tribal areas. In addition, there are many problems women living in tribal areas encounter which hinder effective clothing storage practices. Therefore, there is need for enhancing clothing storage practices for women living in tribal areas.

\section{RECOMMENDATIONS}

Based on the findings of this study, the researchers made the following recommendations for proper clothing storage practices of women in tribal areas:

- Clothing experts and extension workers should organize workshops and seminars in order to educate women on skills involved in clothing and its storage practices.

- Women living in tribal areas should adopt correct and best methods, techniques and strategies for effective clothing storage practices.

- There should be environmental and consumer education provided by educator on the need for creating awareness on the danger of improper clothing storage practices for all women.

- Women living in tribal areas should sit up to attend the entire enlightenment programme on clothing and storage information.

\section{REFERENCES}

Anyakoha EU, Eluwa AS 2007. Home Management for Schools and Colleges. Onitsha: Africana -FEB Publishers Limited.

David N 2009. The impact of internet communication technology (ICT) in rural education: Case study. $\mathrm{Ni}$ geria Journal of Technology, 28(2): 71-79.

Marinda AP 2001. Socio-economic and Psychological Factors Influencing Clothing Preference of the Physically Handicapped in Nairobi Province-Kenya. Master's Thesis, Unpublished. Nairobi: Kenyatta University.

Marshal SG, Jackson OH, Stanley MS, Kefgen M, Touchie SP 2000. Individuality in Clothing Selection and Personal Appearance. New Jersey: Prentice Hall.

Migunde SA 1993. Socio-cultural and Psychological Factors Influencing Clothing Selection of Kenyan Adolescents in Nairobi Province. Master's Thesis, Unpublished. Nairobi: Kenyatta University.

Ohwvoriole PI, Ugeru E 2002. Problems of Clothing Management Practices of Home Makers, Research Issues in Home Economics. Nsukka: ECCE Homo Enterprises.

Okoro OM 1999. Principles and Methods in Vocational and Technical Education. Nsukka: University Trust Publisher.

Otieno OK 1990. Physiological, Psychological and Socio-economic Factors Influencing Clothing Selection and Buying Practices among Kenyans: A Study of Kenyatta University. Master's Thesis, Unpublished. Nairobi: Kenyatta University.

Pitts W, Wessel JK 2006. Silk: Special Fabrics Needs Special Care. From <pro melindameahan@utts66. uucp> (Retrieved on 6 November 2016).

Sharma R, Tiwari M, Sharma M 2008. Rajasthan Ka Vistrit Avlokan. Delhi: Himanshu Publication.

Wilson DJ, Mac Gillivray SM 1998. Self-perceived influences of family, friends and media on adolescent clothing choice.Family and Consumer Science Research Journal, 26(4): 425.

WoodWard C 2006. Clothing Care and Sewing Techniques for Visually Impaired on Total Blind Student's Home Making Teacher. Augustine, Texas. From $<$ http://home.home.howstuffon com/how-to-carefor-your-clothes.htm> (Retrieved on 7 May 2008).

Paper received for publication on August 2017

Paper accepted for publication on December 2017 